\begin{tabular}{|c|c|c|}
\hline$x^{2}$ & $\begin{array}{l}\text { Jurnal Teknologi Kimia Unimal } \\
\text { http://ojs.unimal.ac.id/index.php/jtk }\end{array}$ & $\begin{array}{l}\text { Jurnal } \\
\text { Teknologi } \\
\text { Kimia } \\
\text { Unimal }\end{array}$ \\
\hline
\end{tabular}

\title{
Pemanfaatan Limbah Kaleng Minuman Aluminium sebagai Penghasil Gas Hidrogen menggunakan Katalis Natrium Hidroksida $(\mathrm{NaOH})$
}

\author{
Sri Wahyuni ${ }^{1}$, Lukman Hakim $^{2}$, Fikri Hasfita ${ }^{3}$ \\ 1,2,3 Jurusan Teknik Kimia, Fakultas Teknik, Universitas Malikussaleh \\ Kampus Bukit Indah Kec. Muara Satu, Aceh Utara - Fax (0645) 44450 \\ Korespondensi: HP: 082360997815, e-mail: Sriwahyuni1572@yahoo.com
}

\begin{abstract}
Abstrak
Gas hidrogen tidak dapat ditambang melainkan diproduksi, salah satunya produksi hidrogen dari limbah kaleng minuman aluminium mereaksikannya dengan air dan penambahan natrium hidroksida (NaOH) sebagai katalis. Reaksi tersebut menghasilkan gas hidrogen dan NaAl(OH)4. Dalam konteks ini, hidrogen dapat dikonversikan menjadi energi terbarukan, dimana energi tersebut ramah lingkungan dan emisi yang dihasilkan berupa uap air. Tujuan penelitian ini adalah mengembangkan teknik daur ulang limbah kaleng minuman aluminium seperti Pocari Sweat untuk menghasilkan gas hidrogen sebagai energi yang ramah lingkungan dan dapat diperbaharui. Penelitian ini dilakukandengan mereaksikan aluminium dan air dengan katalis $\mathrm{NaOH}$ selama 43 menit pada suhu 300C. Dimana berat aluminium divariasikan (0.5 gr, $1 \mathrm{gr}, 1.5 \mathrm{gr}$ dan $2 \mathrm{gr})$, serta konsentrasi $\mathrm{NaOH}$ yang divariasikan $(2 \mathrm{~N}, 3 \mathrm{~N}, 4 \mathrm{~N}, 5 \mathrm{~N}$ dan $6 \mathrm{~N})$. Dari hasil penelitian menunjukkan bahwa volume hidrogen terbesar pada berat aluminium 2 gram dengan konsentrasi NaOH 6N yaitu 1,081 liter. Untuk konversi aluminium tertinggi pada berat aluminium 0,5 gram dengan konsentrasi $\mathrm{NaOH}$ 6N yaitu $68,950 \%$, sedangkan yield hidrogen tertinggi pada berat aluminium yaitu 2 gram dengan konsentrasi NaOH $6 \mathrm{~N}$ yaitu 3,539\%.
\end{abstract}

Kata kunci $\quad$ :aluminium, energi terbarukan, hidrogen, katalis, limbah kaleng

\section{Pendahuluan}

Dalam konteks ini, isu utama yang paling menonjol adalah konversi energi dari sebelumnya energi berbasis bahan bakar fosil kini beralih ke energi yang dapat diperbaharui. Di sisi lain, isu lingkungan global yang menuntut tingkat kualitas lingkungan yang lebih baik, mendorong berbagai pakar energi untuk mengembangkan energi yang lebih ramah lingkungan dan mendukung jaminan pasokan berkesinambungan. Hasil penelitian diharapkan mampu mengatasi beberapa permasalahan yang berkaitan dengan penggunaan minyak bumi. Salah 
satu bentuk energi terbarukan yang dewasa ini menjadi perhatian besar pada banyak negara, terutama di negara maju adalah hidrogen. Hidrogen diproyeksikan oleh banyak negara akan menjadi bahan bakar masa depan yang lebih ramah lingkungan dan lebih efisien. Dimana suplai energi yang dihasilkan sangat bersih karena hanya menghasilkan uap air sebagai emisi selama berlangsungnya proses. Gas hidrogen tidak dapat ditambang melainkan harus diproduksi. Alternatif tersebut dapat dilakukan dengan melakukan proses elektrolisis menggunakan air dengan reaksi fotokatalisis oksinitrida (Domen dan Maeda, 2006) atau proses elektrolisis dengan menggunakan katalis oksida padat (Zang dkk, 2010). Metode produksi hidrogen dari biomasa meliputi metode biologi (Claassen dkk, 2010) dan secara kimia (K!rtay, 2011).

Produksi hidrogen juga dapat dilakukan dengan steam reforming dari hidrokarbon (Pencova dkk, 2011). Selain itu, hidrogen dapat dihasilkan dari reaksi logam dan air dengan bantuan katalis. Salah satunya yaitu hidrogen yang dihasilkan dari logam aluminium yang direaksikan dengan air menggunakan katalis $\mathrm{NaOH}$ (Kumar dan Surendra, 2013).

Saat ini, penggunaan aluminium semakin meningkat. Salah satu penggunaan aluminium pada industri minuman ringan (soft drink) dimana aluminium tersebut digunakan sebagai kemasan dari minuman ringan (soft drink). Aluminium biasa dicampur untuk menambah sifat mekanis dan kekuatan, seperti aluminium foil dan kaleng minuman mengandung sekitar 92-99\% aluminium selebihnya yaitu tembaga, seng, magnesiun, mangan, silika, dan logam lainnya dengan tingkat persen yang sedikit (Zamani, 2014).

Kandungan aluminium dari kaleng minuman dapat dilihat pada Tabel 1. Pemanfaatan limbah kaleng minuman untuk bahan menghasilkan suatu energi belum banyak dilakukan. Padahal limbah kaleng minuman aluminium yang cukup banyak bisa diproses menjadi gas hidrogen. Dalam penelitian ini, penulis mengambil penelitian limbah kaleng minuman yang banyak ditemui serta memiliki kandungan aluminium yang banyak terdapat pada kaleng pocari sweat. Menurut Siregar (2010) dalam penelitiannya menunjukkan baik katalis asam dan netral tidak dapat memproduksi gas hidrogen. Sebaliknya dengan menggunakan 
katalis basa kuat, baik itu $\mathrm{NaOH}$ dan $\mathrm{KOH}$ memberikan hasil hidrogen yang lebih tinggi, tetapi pada penggunaan katalis $\mathrm{NaOH}$ waktu reaksi antara aluminium dan air lebih cepat daripada katalis $\mathrm{KOH}$.

Tabel 1. Kandungan Aluminium dari Kaleng Minuman

\begin{tabular}{|c|c|c|c|c|c|}
\hline \multirow{2}{*}{ Parameter } & \multirow{2}{*}{ Satuan } & \multicolumn{4}{|c|}{ Jenis Kaleng } \\
\cline { 3 - 6 } & & Pocari Sweat & Cap Kaki Tiga & Greensands & Coca-Cola \\
\hline Aluminium & $\%$ & 96,38 & 89,74 & 90,87 & 93,28 \\
\hline Magnesium & $\%$ & 1,14 & 3,28 & 2,25 & 1,17 \\
\hline Mangan & $\%$ & 0,75 & 1,93 & 1,21 & 1,04 \\
\hline Besi & $\%$ & 0,51 & 1,79 & 1,52 & 1,72 \\
\hline Silikon & $\%$ & 0,19 & 0,88 & 1,33 & 0,68 \\
\hline tembaga & $\%$ & 0,19 & 2,36 & 1,92 & 1,26 \\
\hline
\end{tabular}

Sumber: (Saputra, 2012)

\section{Metode Penelitian}

\subsection{Alat dan bahan yang digunakan}

Adapun alat-alat yang digunakan dalam penelitian ini adalah erlenmeyer, tutup sumbat erlenmeyer, balon, magnetic stirred, hotplate stirred, gunting, timbangan analitik, termometer, labu ukur, benang, spatula, kaca arloji. Bahan yang digunakan dalam penelitian in adalah limbah kaleng minuman Pocari Sweat, $\mathrm{NaOH}$, dan aquadest.

\subsection{Prosedur kerja}

\subsubsection{Prosedur pembuatan gas hidrogen}

Limbah kaleng minuman dengan merek Pocari Sweat yang dibersihkan catnya dengan menggunakan amplas. Setelah penghilangan cat, kaleng minuman tersebut dipotong dengan ukuran $0,1 \times 0,1 \mathrm{~cm}$ dan ditimbang dengan berat sampel 0,5 gr, 1 gr, 1,5 gr dan 2 gr. Kemudian larutan $\mathrm{NaOH}$ dibuat dengan konsentrasi masing-masing $2 \mathrm{~N}, 3 \mathrm{~N}, 4 \mathrm{~N}, 5 \mathrm{~N}, 6 \mathrm{~N}$. Tahap ini masing- masing potongan kaleng tersebut dimasukkan ke dalam erlenmeyer yang berisi larutan $\mathrm{NaOH}$ dengan konsentrasi masing-masing $2 \mathrm{~N}, 3 \mathrm{~N}, 4 \mathrm{~N}, 5 \mathrm{~N}$,dan $6 \mathrm{~N}$. Kemudian ditutup mulut erlenmeyer dengan menggunakan penutup karet. 
Pengukuran suhu dilakukan dengan menggunakan termometer. Suhu dijaga pada suhu $30^{\circ} \mathrm{C}$. Untuk menjaga suhu reaksi digunakan water bath sebagai media pendingin. Waktu reaksi dijaga selama 43 menit dengan pengadukkan $100 \mathrm{rpm}$. Pengumpulan gas hidrogen digunakan balon yang letakkan pada permukaan erlenmeyer. Sebelum volume gas hidrogen dapat dihitung, terlebih dalulu keliling balon diukur. Persamaan yang digunakan adalah:

$$
\begin{aligned}
& K=u \cdot d \\
& V=\frac{4}{3} u \cdot r^{3}
\end{aligned}
$$

\subsubsection{Penentuan konversi, yield, dan pengujian gas hidrogen dengan cara pembakaran}

Konversi dan yield ditentukan dengan menggunakan persamaan di bawah ini (Dave dan Pant, 2010):

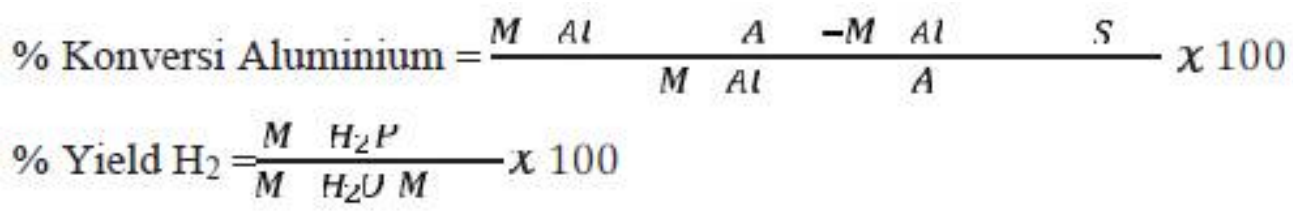

Untuk mengidentifikasi dan memastikan telah dihasilkan hidrogen dalam reaksi yaitu dengan melakukan pengujian pembakaran gas hidrogen dengan menggunakan botol dan balon. Gas hidrogen sangat mudah terbakar dan akan terbakar pada konsentrasi serendah $4 \%$ di udara bebas. Karakteristik lainnya dari api hidrogen adalah nyala api cenderung menghilang dengan cepat di udara, sehingga kerusakan akibat ledakan hidrogen lebih ringan dari ledakan hidrokarbon (College Of Desert,2001).

\section{Hasil dan Pembahasan}

Dalam suhu kamar, reaksi aluminium dengan air untuk membentuk aluminium hidroksida dan hidrogen adalah sebagai berikut:

$$
2 \mathrm{Al}_{(\mathrm{s})}+6 \mathrm{H}_{2} \mathrm{O}_{(\mathrm{l})} \longrightarrow 2 \mathrm{Al}(\mathrm{OH})_{3(\mathrm{~s})}+3 \mathrm{H}_{2}(\mathrm{~g})
$$


Reaksi ini secara termodinamika terjadi dari suhu kamar yang bersifat eksoterm. Reaksi ini juga harus terjadi spontan. Namun, dalam prakteknya sepotong aluminium jatuh ke air tidak akan bereaksi dalam kondisi suhu kamar, atau bahkan dengan air mendidih. Hal ini karena aluminium bereaksi lambat dengan air karena mudah bereaksi dengan oksigen membentuk lapisan aluminium oksida (A12O3) di permukaan dan lapisan alumina ini mencegah reaksi (Departement Of Energy, 2008). Oleh karena itu, untuk memperoleh hasil yang optimal aluminium harus diampelas dulu sebelum direaksikan untuk menghilangkan lapisan oksida yang menutupi permukaan aluminium. Karena kecenderungannya yang kuat dioksidasi menjadi $\mathrm{Al}^{3+}$, diharapkan $\mathrm{Al}(\mathrm{s})$ dapat menggantikan $\mathrm{H}_{2}$ (g) dari air (Petrucci, 1993).

Dalam penelitian ini, pembuatan gas hidrogen dari limbah kaleng minuman aluminiun menggunakan Natrium Hidroksida $(\mathrm{NaOH})$ yang bertindak sebagai katalis dalam reaksi untuk mempercepat reaksi. Natrium hidroksida $(\mathrm{NaOH})$ adalah bahan kimia berbentuk kristal putih padat yang apabila memasuki lingkungan akan mudah bereaksi memecah dengan bahan kimia lain. Seperti halnya natrium hidroksida dimasukkan dalam air akan memisahkan kation natrium (sodium atom bermuatan positif) dan anion hidroksida (oksigen dan hidrogen atom bermuatan negatif). Natrium hidroksida mudah larut dalam air dan akan menghasilkan panas (eksoterm). Ion $\mathrm{OH}^{-}$pada larutan alkali tersebut akan menjadi promotor pada reaksi aluminium dengan air. Ketika reaksi antara Al dan air dibantu oleh alkali, ion $\mathrm{OH}^{-}$dapat merusak lapisan oksida pelindung pada permukaan aluminium (Kumar dan Surendra, 2013).

Reaksi antara aluminium dan air dengan Natrium Hidroksida $(\mathrm{NaOH})$ untuk produksi hidrogen dapat ditunjukkan pada reaksi dibawah ini:

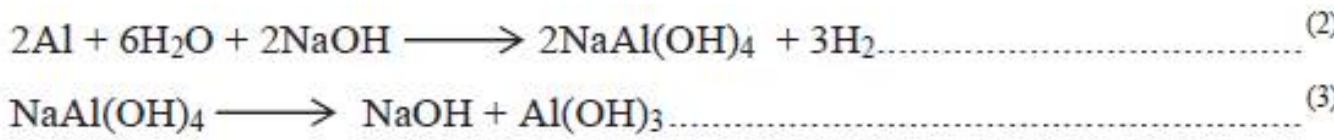

Natrium hidroksida $(\mathrm{NaOH})$ dikonsumsi untuk produksi hidrogen dengan reaksi eksoterm (3) dan akan diproduksi ulang melalui reaksi dekomposisi $\mathrm{NaAl}(\mathrm{OH}) 4$. Reaksi (4.4) akan menghasilkan endapan kristal aluminium 
hidroksida $(\mathrm{Al}(\mathrm{OH}) 3)$. Kombinasi dari dua reaksi diatas menunjukkan bahwa hanya air yang dikonsumsi untuk produksi hidrogen jika dilihat dari reaksi tersebut (Kumar dan Surendra, 2013).

Pada saat potongan kaleng aluminium dimasukan kedalam erlenmeyer yang berisi larutan natrium hidroksida terjadi gelembung-gelembung pada potongan kaleng tersebut, selanjutnya gas yang dihasilkan ditampung menggunakan dengan balon yang dapat di lihat pada Gambar (a). Untuk mengidentifikasi dan memastikan telah dihasilkan hidrogen dalam reaksi yaitu dengan melakukan pengujian pembakaran gas hidrogen seperti terlihat pada Gambar 1 (b) dan (c).

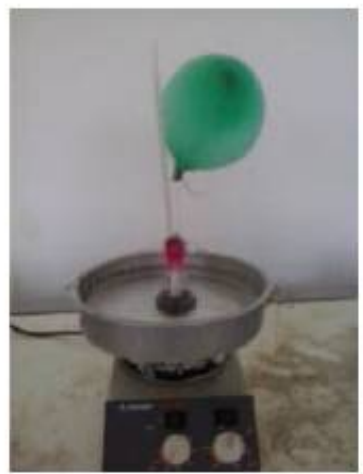

(a)

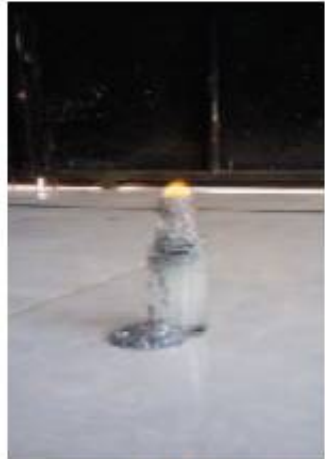

(b)

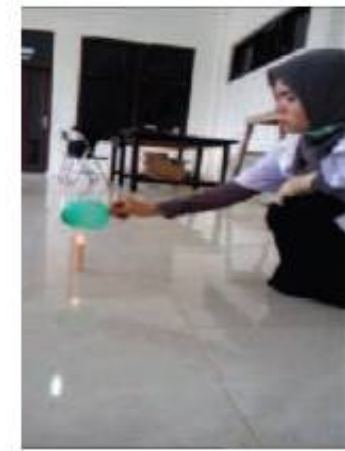

(c)

Gambar 1. Pembuatan dan Pengujian Gas hidrogen. (a) Penampungan gas hidrogen dengan balon. (b) Pembakaran gas hidrogen dengan botol. (c) Pembakaran gas hidrogen dengan menggunakan balon.

\subsection{Pengaruh konsentrasi natrium hidroksida ( $\mathrm{NaOH})$ dan jumlah aluminium terhadap volume gas hidrogen}

Analisa kimia kuantitatif digunakan untuk mendapatkan data mengenai produksi gas hidrogen yang dihasilkan dari reaksi antara limbah kaleng minuman aluminium dengan larutan natrium hidroksida $(\mathrm{NaOH})$ dari konsentrasi $(2 \mathrm{~N}, 3 \mathrm{~N}$, $4 \mathrm{~N}, 5 \mathrm{~N}$, dan $6 \mathrm{~N})$ dengan jumlah aluminium (0,5 gr, 1 gr, 1,5 gr dan 2 gr). Pengukuran dilakukan untuk mengetahui pengaruh berat kaleng minuman aluminium terhadap volume gas hidrogen yang dihasilkan. Berikut ini pengaruh berat aluminium terhadap volume gas hidrogen dengan variasi konsentrasi ditunjukkan pada Gambar 2. 
Dalam penelitian ini waktu reaksi ditetapkan pada 43 menit, mengikuti penelitian yang dilakukan Siregar (2012) pada jumlah aluminium 0,1 gr dengan konsentrasi $\mathrm{NaOH}$ tertinggi yaitu $15 \%$ waktu reaksi aluminium dan air dengan natrium hidroksida $(\mathrm{NaOH})$ dibutuhkan sekitar 1826,7 detik atau 30 menit 26 detik telah menghasilkan hidrogen. Pada Gambar 2 menunjukkan volume hidrogen bertambah dengan kenaikan konsentrasi $(2 \mathrm{~N}, 3 \mathrm{~N}, 4 \mathrm{~N}, 5 \mathrm{~N}$, dan $6 \mathrm{~N})$. Pada konsentrasi tertinggi yaitu $6 \mathrm{~N}$ volume hidrogen yang dihasilkan lebih besar dibandingkan konsentrasi 5N, 4N, 3N, dan 2N. Hal ini dapat disimpulkan bahwa dalam penelitian ini semakin tinggi konsentrasi natrium hidroksida $(\mathrm{NaOH})$ volume hidrogen makin bertambah. Ini dikarenakan larutan $\mathrm{NaOH}$ berfungsi membantu aluminium mengikat $\mathrm{OH}$ - dari air membentuk $\mathrm{NaAl}(\mathrm{OH}) 4$, sehingga melepaskan hidrogen, seperti yang ditunjukkan pada reaksi (2) dan (3) (Kumar dan Surenda, 2013).

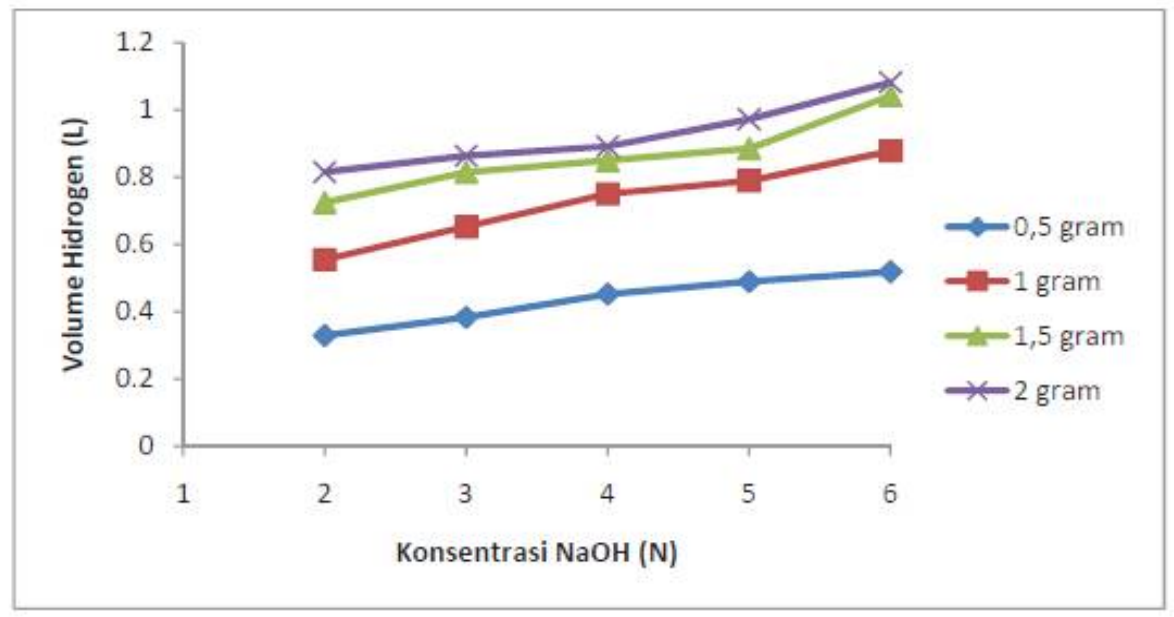

Gambar 2. Hubungan pengaruh konsentrasi $\mathrm{NaOH}$ dan jumlah aluminium terhadap volume gas hidrogen

Berdasarkan Gambar 2 dapat dilihat jumlah aluminium terhadap volume gas hidrogen adalah semakin besar jumlah limbah aluminium yang diberikan semakin besar pula volume hidrogen yang dihasilkan. Terlihat bahwa semakin tinggi jumlah aluminium (0,5 gr, 1 gr, 1,5 gr, dan 2 gr) volume hidrogen yang dihasilkan semakin bertambah. Dalam penelitian ini volume hidrogen terbesar pada berat aluminium 2 gr dengan konsentrasi 6N yaitu 1,081 liter. Berdasarkan 
penelitian Porciuncula dkk (2012) mengatakan produksi hidrogen dipengaruhi oleh suhu, konsentrasi alkali, dan bentuk logam. Siregar (2012) mengatakan bahwa semakin tinggi jumlah aluminium, maka gas hidrogen yang dihasilkan semakin besar, sedangkan laju reaksi tertinggi pada konsentrasi $\mathrm{NaOH}$ tertinggi.

\subsection{Pengaruh konsentrasi natrium hidroksida $(\mathrm{NaOH})$ dan jumlah aluminium terhadap konversi aluminium}

Reaksi aluminium dan air dengan natrium hidroksida $(\mathrm{NaOH})$ membentuk $\mathrm{NaAl}(\mathrm{OH})_{4}$ dan hidrogen. Dalam reaksi tersebut aluminium akan mengalami oksidasi sehingga menghasilkan $\mathrm{Al}^{3+}$, sedangkan $\mathrm{H}^{+}$dari air akan mengalami reduksi menjadi $\mathrm{H}_{2}$. Seperti yang ditunjukkan pada persamaan reaksi (2) dan (3) pada dasarnya, hanya air yang dihabiskan selama seluruh proses untuk menghasilkan hidrogen. Dalam reaksi tersebut aluminium mengikat $\mathrm{OH}^{-}$dari senyawa air membentuk $\mathrm{NaAl}(\mathrm{OH})_{4}$ sehingga melepaskan hidrogen. Pengaruh konsentrasi natrium hidroksida $(\mathrm{NaOH})$ dan jumlah aluminium terhadap konversi aluminium dapat dilihat pada Gambar 3.

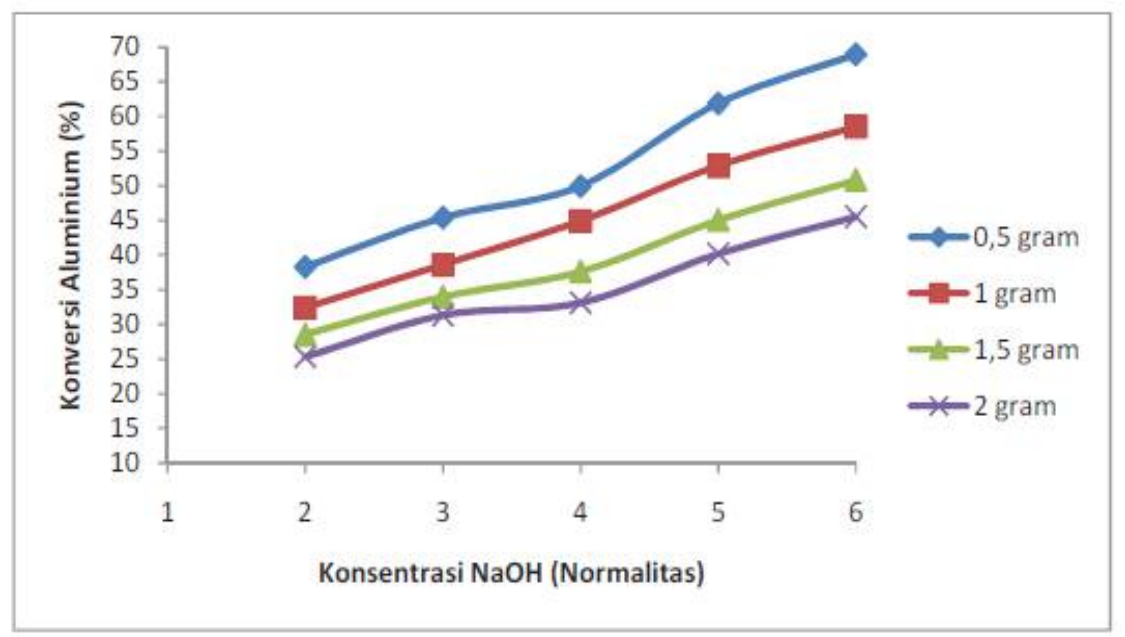

Gambar 3. Pengaruh konsentrasi natrium hidroksida $(\mathrm{NaOH})$ dan jumlah aluminium terhadap konversi aluminium

Berdasarkan waktu reaksi selama 43 menit dapat dilihat pada Gambar 3 bahwa pengaruh konsentrasi $\mathrm{NaOH}$ terhadap konversi aluminium, semakin tinggi konsentrasi $\mathrm{NaOH}(2 \mathrm{~N}, 3 \mathrm{~N}, 4 \mathrm{~N}, 5 \mathrm{~N}$, dan $6 \mathrm{~N})$ maka konversi aluminium semakin 
tinggi. Hal ini dikarenakan pada konsentrasi $\mathrm{NaOH}$ yang lebih tinggi menunjukkan jumlah $\mathrm{NaOH}$ lebih banyak. $\mathrm{NaOH}$ adalah sebagai katalis reaktif yang dapat merusak lapisan oksida $\left(\mathrm{Al}_{2} \mathrm{O}_{3}\right)$ pelindung pada permukaan aluminium serta membantu aluminium mengikat $\mathrm{OH}^{-}$dari air membentuk $\mathrm{NaAl}(\mathrm{OH})_{4}$ sehingga melepaskan hidrogen.

Jumlah aluminium berdasarkan Gambar 3 menunjukkan bahwa semakin banyak jumlah aluminium (0,5 gr, 1 gr, 1,5 gr, dan 2 gr) maka konversi aluminium terhadap produk hidrogen semakin rendah. Gambar 3 menunjukkan bahwa konversi aluminium tertinggi diperoleh pada berat aluminium 0,5 gr konsentrasi $6 \mathrm{~N}$ sekitar 68,950\%. Konversi aluminium sangat berpengaruh terhadap jumlah aluminium dan konsentrasi $\mathrm{NaOH}$. Hal ini disebabkan karena natrium hidroksida $(\mathrm{NaOH})$ bertindak sebagai katalis yang dapat menurunkan energi aktivasi sehingga mampu meningkatkan laju reaksi agar reaksi dapat mencapai kesetimbangan, tanpa terlibat didalam reaksi secara permanen. Energi aktivasi adalah energi minimum yang dibutuhkan sehingga partikel dapat bertumbukan dan menghasilkan reaksi. Dalam penggunaan katalis tersebut, energi aktivasi harus cukup agar reaksi tersebut mencapai kesetimbangan. Apabila energi aktivasi dalam reaksi tersebut tinggi maka reaksi tersebut akan berjalan lambat (Widhyahrini, 2013).

\subsection{Pengaruh konsentrasi natrium hidroksida $(\mathrm{NaOH})$ dan jumlah Aluminium terhadap yield hidrogen}

Berdasarkan dari reaksi (2) dan (3) menunjukkan bahwa hidrogen yang dihasilkan berasal dari senyawa air. Sedangkan konsentrasi natrium hidroksida $(\mathrm{NaOH})$ yang bertindak sebagai katalis akan mempengaruhi laju reaksi dan membantu aluminium mengikat $\mathrm{OH}^{-}$dari air membentuk $\mathrm{NaAl}(\mathrm{OH})_{4}$ dan hidrogen. Berdasarkan penelitian yang telah dilakukan, pengaruh konsentrasi natrium hidroksida $(\mathrm{NaOH})$ dan jumlah aluminium terhadap yield hidrogen dapat dilihat pada Gambar 4.

Berdasarkan hasil penelitian yang dilakukan dengan waktu reaksi selama 43 menit, dapat dilihat pada Gambar 4 bahwa semakin tinggi konsentrasi $\mathrm{NaOH}(2 \mathrm{~N}$, 
$3 \mathrm{~N}, 4 \mathrm{~N}, 5 \mathrm{~N}$, dan $6 \mathrm{~N}$ ) maka yield hidrogen yang dihasilkan semakin tinggi, dan sebaliknya semakin rendah konsentrasi $\mathrm{NaOH}$ maka yield hidrogen yang dihasilkan semakin rendah. Hal ini dikarenakan $\mathrm{NaOH}$ adalah sebagai katalis reaktif yang dapat merusak lapisan oksida $\left(\mathrm{Al}_{2} \mathrm{O}_{3}\right)$ pelindung pada permukaan aluminium (Departement of Energy, 2008) serta membantu aluminium mengikat $\mathrm{OH}$ - dari air membentuk $\mathrm{NaAl}(\mathrm{OH}) 4$ sehingga melepaskan hidrogen, seperti yang ditunjukkan pada reaksi (2) dan (3) (Kumar dan Surenda, 2013).

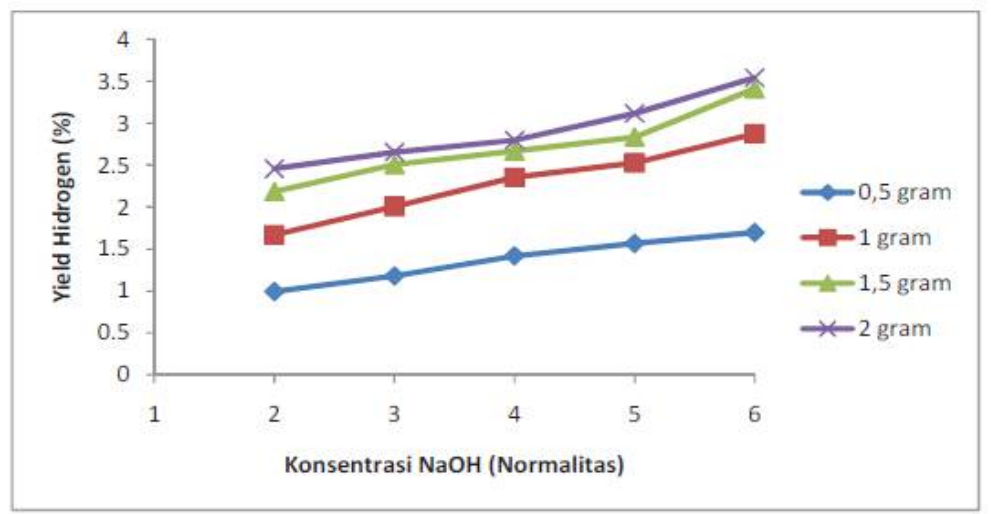

Gambar 4. Pengaruh konsentrasi natrium hidroksida $(\mathrm{NaOH})$ dan jumlah aluminium
terhadap yield hidrogen

Jumlah aluminium berdasarkan Gambar 4 dapat dilihat pada berat aluminium (0,5 gr, 1 gr, 1,5 gr, dan 2 gr), semakin tinggi jumlah aluminium maka gas hidrogen yang dihasilkan semakin besar. Dalam penelitian Siregar (2012) menunjukkan bahwa semakin tinggi jumlah aluminium hidrogen yang dihasilkan semakin besar. Dari Gambar 4 terlihat bahwa yield hidrogen tertinggi pada berat aluminium 2 gr dengan konsentrasi 6N sekitar 3,539\%. Berdasarkan reaksi (2) dan (3) sama-sama menghasilkan reaksi (1) bahwa hanya air yang dikonsumsi untuk menghasilkan hidrogen. Dari reaksi (1) aluminium mengikat $\mathrm{OH}^{-}$dari senyawa air membentuk $\mathrm{Al}(\mathrm{OH})_{3}$ sehingga melepaskan hidrogen. Hal ini menunjukkan bahwa semakin banyak jumlah aluminium maka hidrogen yang dihasilkan semakin besar, sebab banyak aluminium mengikat $\mathrm{OH}^{-}$dari air mengakibatkan hidrogen lepas dari senyawa air tersebut. 
Sri Wahyuni dkk. / Jurnal Teknologi Kimia Unimal 6 : 2 (November 2017) 31 - 42

\section{Kesimpulan dan Saran}

Berdasarkan hasil penelitian maka dapat diambil kesimpulan bahwa volume hidrogen tertinggi pada berat aluminium 2 gr dengan konsentrasi $\mathrm{NaOH} 6 \mathrm{~N}$ yaitu 1,0818 liter. Konversi aluminium produk hidrogen yang tertinggi terdapat pada berat aluminium 0,5 gr dengan konsentrasi natrium hidroksida $(\mathrm{NaOH}) 6 \mathrm{~N}$ yaitu $68,950 \%$, sedangkan yield hidrogen yang tertinggi terdapat pada berat aluminium 2 gr dengan konsentrasi natrium hidroksida $(\mathrm{NaOH}) 6 \mathrm{~N}$ yaitu 3,539\%. Natrium hidroksida $(\mathrm{NaOH})$ berfungsi sebagai katalis dalam reaksi aluminium dan air, serta membantu aluminium mengikat $\mathrm{OH}^{-}$dari senyawa air membentuk $\mathrm{NaAl}(\mathrm{OH}) 4$ sehingga melepaskan hidrogen.

Adapun saran yang dapat diberikan dari hasil penelitian ini adalah waktu reaksi untuk menghasilkan hidrogen dari reaksi aluminium dan air dengan katalis $\mathrm{NaOH}$ divariasikan lebih lama dari 43 menit untuk mengkonversikan reaktan lebih tinggi dan pemanfaatan limbah aluminium perlu dilakukan terutama yang banyak mengandung aluminium sebagai sumber penghasil hidrogen.

\section{Daftar Pustaka}

Claassen,P.A.M., Truus de, V., Emmanuel, K., Ed van, N., Inci, E., Michael, M., Anton, F., Walter, W., Werner, A (2010), .Non-thermal production of pure hydrogen from biomass: HYVOLUTION., Journal of Cleaner Production, 18,54-58.

College Of The Desert (2001), .Modul 1 Hydrogen Properties., Hydrogen Fuel Cell Engines and Related

Technologies,http://www1.eere.energy.gov/hydrogenandfuelcells/tech_validation/ pdfs/fcm01r0.pdf diakses pada 7 Desember 2015.

Domen, K., dan Maeda K., (2006), Hydrogen Producrion from Water on Oxinitride Photocatalysts., The International Society for Optical Engineering, 1-3

Dave, C. D., dan Pant, K. K., (2011), .Renewable Hydrogen Generation by Steam Reforming of Glycerol Over Zirconia Promoted Ceria Support Catalyst., Renewable Energy An International Journal, 1-8.

Departement Of Energy, (2008), .Reaction Of Aluminium with Water to Produce Hydrogen., United States Of America, 
https://www1.eere.energy.gov/hydrogenandfuelcells/pdfs/aluminium_water_hydr ogen.pdf diakses pada 5 Februari 2016

K!rtay, E., (2011), " Recent advances in production of hydrogen from biomass., Journal of Energi Conversion and Management, 52, 1778.1789.

Kumar, S. dan Surendra K. S., (2013), .Role Of Sodium Hydroxide For Hydrogen Gas Production And Storage., College of Engineering and Computing, Florida International University, Miami, Florida 33199, USA.

Penkova A., Bobadillaa, L., Ivanova, S., Dominguez, M.I., Romero-Sarriaa, F., Roger, A.C., Centeno, M.A., Odriozola, J.A., (2011), Hydrogen production by methanol steam reforming on NiSn/MgO.Al2O3catalysts: The role of $\mathrm{MgO}$ addition., Journal of Applied Catalysis A, General 392, 184.191.

Petrucci, R. H., (1996), Kimia Dasar. Jakarta: Erlangga.

Porciuncula, C.B., Marcillo, N. R., Tessaro, I. C., Gerchmann, M., (2010), Production of Hydrogen in the Reaction Between Aluminum and Water in the Presence of $\mathrm{NaOH}$ and $\mathrm{KOH} .$, Brazilian Journal of Chemical Engineering, Vol. 29 No. 2, ISSN 0104-6632.

Saputra, A. D., (2012)., Sintesis Tawas Kalium Aluminium Sulfat (Kal(SO4)2.12H2O) Dari Kaleng Bekas Minuman Sebagai Zat Penjernih Air. Skripsi. Bogor: Fakultas Matematika dan Ilmu Pengetahuan. Universitas Pakuan Bogor.

Siregar, Y. D. I., (2010), . Produksi Gas Hidrogen dari Limbah Aluminium.. Jurnal Valensi, Volume 2, No. 1: 362-36.

Siregar, Y. D. I., (2012), . Produksi Gas Hidrogen dari Limbah Aluminium dan Uji Daya Listrik dengan Fuel Cell., Portal Garuda, Volume 2, No.5: 573580.

Widhyahrini,K., (2013), .Katalis.. http://duniakimianana.wordpress.com/2013. 04/21/katalis/ diakses pada 11 November 2015

Zamani,H. A., Mina, R., Mohammad, R. A., Soraia, M., (2014), . Al3+-Selective PVC Membrane Sensor Based on Newly Synthesized 1,4-bis[o-(pyridine2-carboxamidophenyl)]-1,4-dithiobutane as Neutral Carrier., International Journal Of Electrochemical Science, 9, 6495 - 6504.

Zhang, H., Guoxing, L., Jincan, C., (2010), . Evaluation and calculation on the efficiency of a water electrolysis system for hydrogen production., International Journal of Hydrogen Energi, 35, 10851- 10858. 